\title{
Developing Character Education Management Model For The Empowerment Of Ethos Transformation Based Multiple-Intelligence Of Junior High School Students
}

\author{
Abdul Kadim Masaong, \\ Faculty of Education, State University of Gorontalo \\ akmas2009@yahoo.co.id
}

Asrin

Faculty of Education, State University of Gorontalo bajangasrin@gmail.com

\author{
Ikhfan Haris \\ Faculty of Education, State University of Gorontalo \\ ihfanharis@ung.oc.id \\ Sutrisno D.J. Yunus \\ State Elementary School Tobongo \\ sutrisnoyunus@yahoo.co.id
}

\begin{abstract}
This research is aimed at developing character education management model to empower ethos transformation based multiple-intelligence of junior high school students that covers: Guidelines on its basic concepts, program, implementation, and monitoring and evaluation of character education model. The research applies the model developed by Borg and Gall (2003) that covers these five steps: (1) analyze the book model products of education character management that will be developed, (2) develop initial products, (3) apply expert validation and revise, (4) conduct a small scale field trial and revise the products, and (5) apply a large scale field trial and finalize the products. These are the results of the first year research: (1) developed Book I Draft on Basic Concepts of Multiple-Intelligence based Education Management; (2) developed Book II Draft on Multiple-Intelligence based Character Education Program Model; (3) developed Book III Draft on Implementation Guidelines on Multiple-Intelligence based Character Education; and (4) developed Book IV on Monitoring and Evaluation Guidelines on Multiple-Intelligence based Character Education Management.
\end{abstract}

Key Words: Character education management, ethos transformation, multiple-intelligence

\section{INTRODUCTION}

Indonesia has recently been encountered with tremendous moral crisis issues, i.e. sexual abuse to children, corruption that is equally spread in all lines of government institutions, mass fighting of students, and increasing numbers of students as victims in the consumption of drugs and alcohol. Indonesia has even been predicted to be a failing country as Egypt [1]. This is caused by the moral degradation of the young generation of the country and its cultural values that are getting worst [2]; [3]. Educational institutions in the country are claimed to be failing in fulfilling the purpose of education that is to develop the country's characters that are competitive and packed with nationalism. On the other hand, the schools are demanded to implement character education initiatives through various strategies to get the purpose of education outlined in the Regulation Number 20 Year 2003 on National Education System fully achieved.

Character education has become the fundamental need in the national education system to create students with good characters, who have knowledge, feelings, and actions [4]. Character education attempts to educate students to have lifedriven values to succeed at schools, in families, and among the wider communities [5]. In the context of schools, character education leads towards the efforts to create ethos transformation of students through character education activities, e.g. intracurricular and extracurricular as well as academic and non-academic activities [6].

To strengthen the role of education in empowering the country's characters, Indonesian President Susilo Bambang Yodoyono declared the main agenda of the national education on 2 May 2010, i.e. (1) education and character building; (2) education and readiness to live; (3) education and work field; (4) knowledgeable community development; and (5) innovative culture development. The agenda is supported by the current Indonesian's president, Joko Widodo, by the launching of the mental revolution program (ethos transformation), also known as the strategic program of "Nawacita".

Character education is about moral character, which involves knowledge, feelings and actions. Lickona [7] states that character education will not be effective without the three aspects. Character education is defined by Suyanto (2010) as the nine pillars of character that comes from the universa values, i.e. (1) love character of God and God's creations; (2) independence and responsibility; (3) honesty/reliability; (4) respect and nobility; (5) generosity, support, and cooperation; (6) self-confidence and hard work; (7) leadership and justice; 
(8) kindness and humility; and (9) tolerance, peace, and unity [8].

Kashwer (2009) suggest that the character education program must be implemented in effective management with involving principals, staff and school personnel. Ineffective implementation of character education in schools of Indonesia inspires the writer to generate solutive ideas through this research: "The Development of Character Education Management Model for the Empowerment of MultipleIntelligence based Ethos Transformation of Junior High School Students in the Gorontalo Province of Indonesia" [9]. The research is aimed at generating the character education management model in schools at the national level to create the golden generation towards the 100 years of Indonesian Independence in 2045.

\section{METHODOLOGY}

This research is a developmental research on character education model management to empower multipleintelligence based ethos transformation. Research method will develop and implements a book models of education character management that empower multiple-intelligence based ethos transformation. The book's model has been developed and analyzed with experts validity has been impelemented for small group of student. The model have been implemented to many schools will be evaluated to understand how an effectiveness the character education management has been done for junior high schools student.

The model refers to the ideas of Borg and Gall (2003) on these five steps, i.e.: (1) analyze products that will be developed, (2) develop initial products, (3) apply expert validation and revise, (4) conduct a small scale field trial and revise the products, and (5) apply a large scale field trial and finalize the products [10]. The first year research is aimed at generating a book draft as the initial product and conducting a small scale expert validation as seen in the following flow chart of the research: Here, circle of research diagram model of character education management;

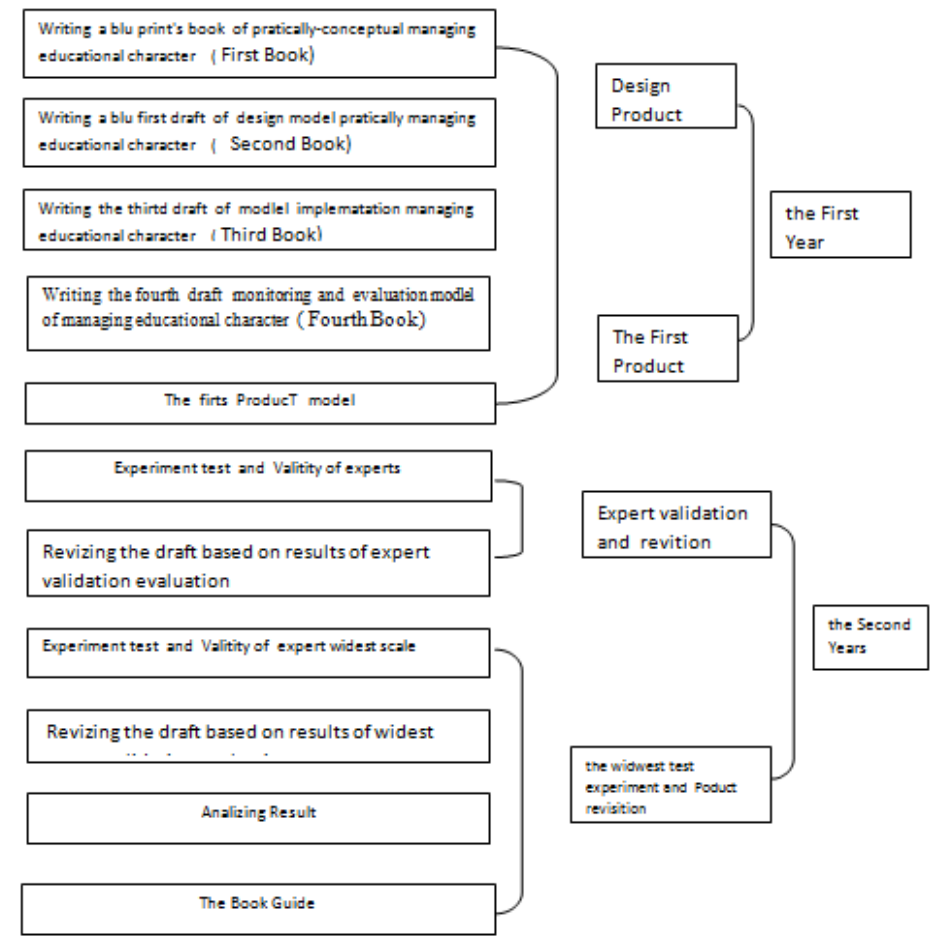

Figure 1. Circle diagram of the book guide development

\section{FINDINGS AND DISCUSSIONS}

1. The Development of Multiple-Intelligence based Character Education Model (IESQ)

The multiple-Intelligence based on Intellectual Quotation, Spiritual Quotient and Emotional Quotient that source of character education at junior high school student [11]; [12]. The IQ, EQ, SQ will give impact to school culture, ethos transformation and student character building. This is the conceptual diagram of multipleIntelligence that cover frame work of this research. 


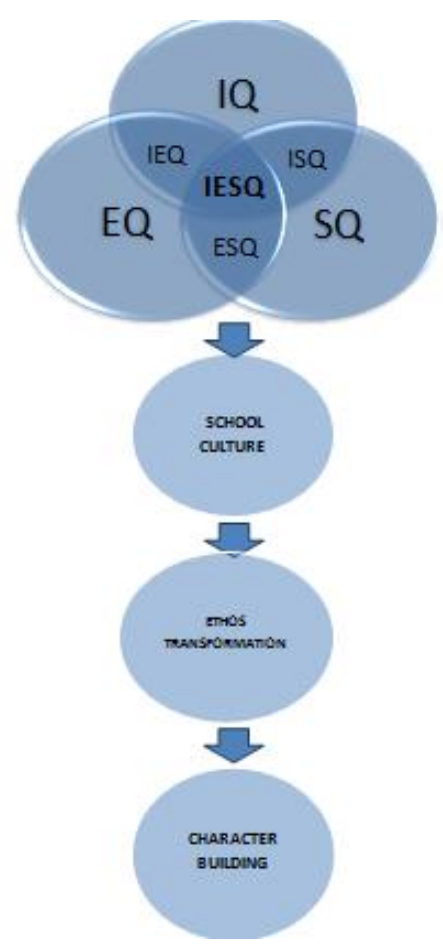

Figure 2. Conceptual diagram of the model development of multiple-intelligence for ethos transformation.

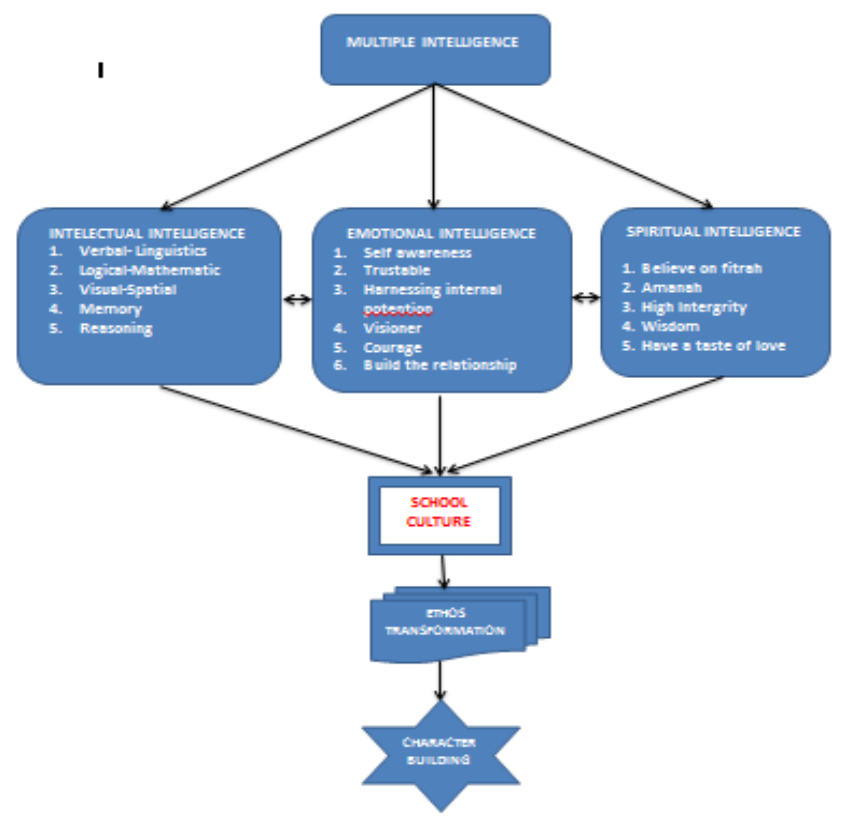

Figure 3. Specific values of multiple-intelligence based character education

Multiple-intelligence based ethos transformation process of students is one of the strategic purposes of character education at schools as it relates with the effort to create a better blueprint of self-quantum change in students [13]; [14]; [15]. This can be developed by intellectual, emotional, and spiritual intelligences (IESQ). Their values are fundamental ideas, perceived as good or correct by most organizational members. The organizational values are defined as school culture in the school context. Values and beliefs are philosophical foundations of schools. Caldwell and Spink (1993) state that values and beliefs at schools impact on school excellence, i.e. quality, effectiveness, equality, efficiency, and empowerment [16]. Ekosusilo (2003) states that school excellence is supported by fundamental values such as excellence, service, and responsibility. Schools develop values and beliefs to become good schools. On the other hand, norms are a set of requirements that exist naturally in a group to be followed by all (culture) [17].

Culture covers philosophy, life perspectives, values, symbols, organizational designs, and relationship patterns among organizational working units [18]. It also relates with transformative values developed at schools. Professionally managed character development of students impacts on created school culture that is reflected on school values, symbols, and activities. Excellent school culture is the result of developing transformative values inside and outside classroom activities. School culture includes school values, symbols, and activities that reflect character development through education process. Religious and local culture values can develop at schools as the basis for students to think, feel, and act towards excellent achievement. Multipleintelligence based school culture development to create excellent achievement of students can be seen in the following diagram:

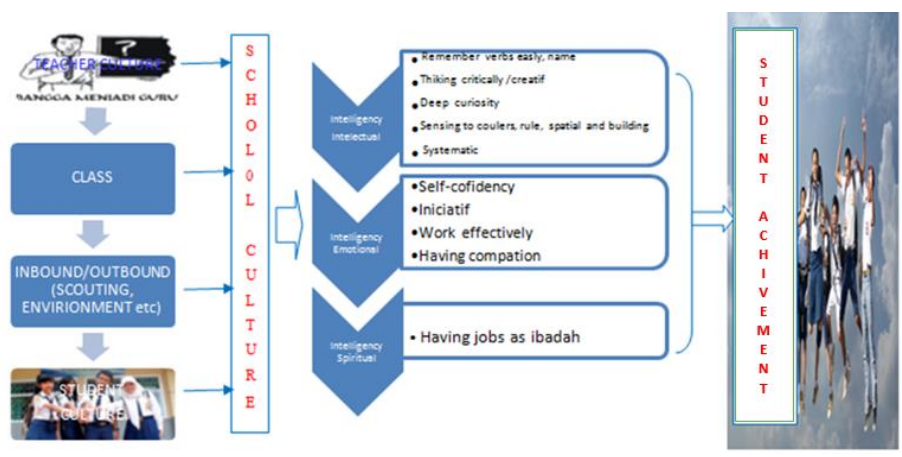

Figure 4. Diagram of multiple-intelligence based school culture development to create excellent achievement of students

Multiple-intelligence based character development at schools covers these three stages, i.e. (1) character education integrated with all subjects; (2) inbound activities; and (3) outbound activities. Model design of implementing integrative, inbound and outbound activities can be seen in the following figure: 


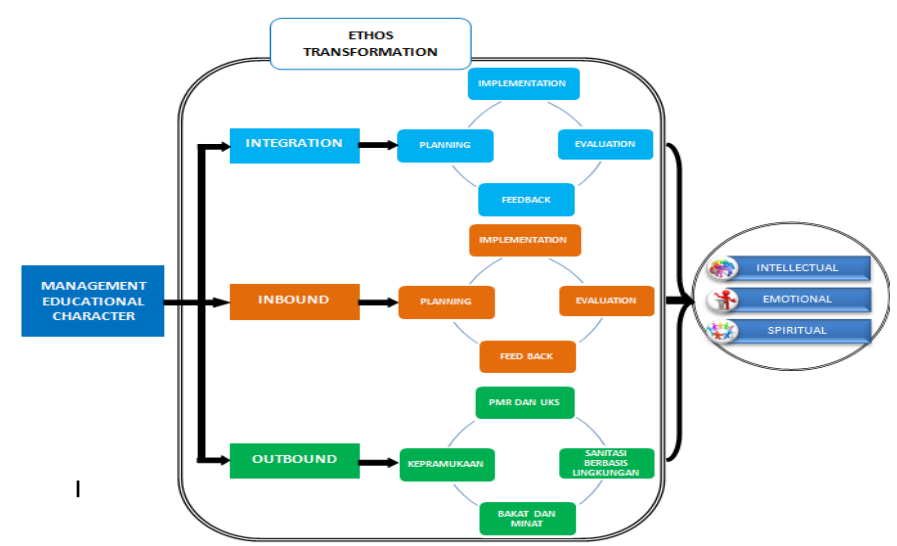

Figure 5. Model Design of Implementing Character Education Management Based on Multiple Intelligence

The development of multiple-intelligence based character values in subjects is carried out at schools through planning the themes or sub-themes of all subjects as outlined in the lesson plans. The purpose is for the teachers to have the guidelines in delivering the plans in classrooms [19]. The development of multiple-intelligence based character values is carried out through these steps: a) review basic competences and indicators on the syllabi; b) determine multipleintelligence based character values that will be integrated with the basic competences and indicators; c) include multipleintelligence based character values in lesson plans; d) develop teaching and learning process that enables students to internalize values in appropriate behaviors; and e) provide assistance to students to internalize values in their daily behaviors.

Integration of character values in planning teaching and learning is actualized through teaching and learning process by using contextual teaching and learning models such as jigsaw, think-pair-share, round-table, and Student Team Achievement Divisions (STAD). Teachers can also use scientific approaches such as problem-based learning, projectbased learning, discovery learning and other approaches that encourage students to learn proactively and independently [20]; [21].

Developing character values in teaching and learning by using various models creates meaningful teaching and learning environment and helps students transform the multiple-intelligence based character values in their life context. Evaluation and feedback are also provided to identify the achieved success in implementing teaching and learning that integrates multiple-intelligence based character values.

Inbound activities can be conducted in different ways by using tools or without tools to test intelligence and skills of students in problem-solving. The activities can be done in the stages of planning, implementation, evaluation, and feedback.

Planning inbound activities is done by preparing tools and ensuring that students can follow the activities appropriately. The enjoyable activities are done to develop the ability and the skills of students to implement character values. They are done to help students get meaningful lessons learned. They can be integrated with these activities, e.g. boy scout, red-cross/health unit, environment based sanitation, and talent and interest. They can also be integrated in teaching and learning activities through ice-breaking.

Outbound activities are designed to be implemented through boy scout, red-cross/health unit, environment based sanitation, and talent and interest. Every activity has some sub-activities that are designed to be practical as the guidelines for teachers to get them delivered effectively. Character values developed in every activity are different, depending on the substance of the activity. More various an activity is, more various the multiple-intelligence based character values are performed.

Successful indicators in the activities are students who are creative and have the initiative to design and set a stretcher and to get pillars for laundry and flag set; these require skills in making knots with ropes. Required tools for the activities include: a) two boy scout sticks; b) sufficient boy scout ropes; c) short sticks; d) two $60 \mathrm{~cm}$ sized pillar sticks; and e) mitella (if available). The activities help students develop skills in making different knots, i.e. basic knot, anchor knot, and cross knot. By the skills they can design a stretcher and get it set, and set pillars for laundry and flag as outlined in the expected indicators. Multiple-intelligence based character values in the activities with the ropes can be seen in the following picture

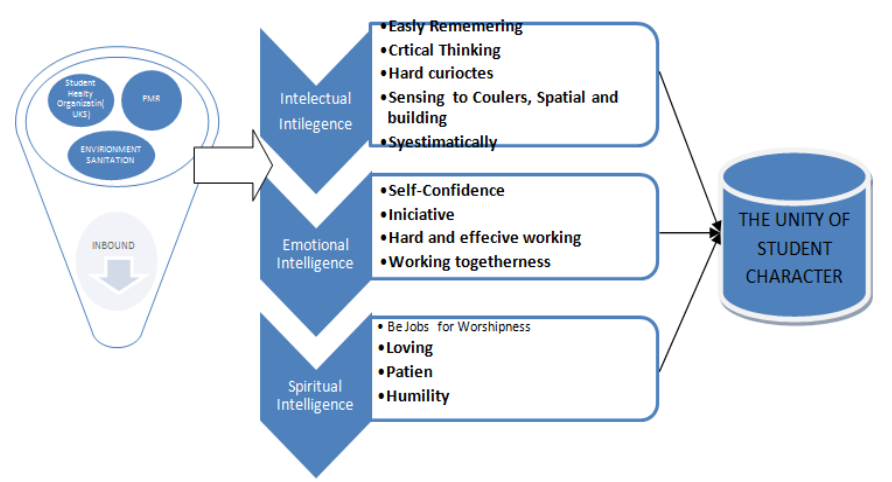

Figure 6: Examples of character values developed in the outbound activities

The cultivation of multiple-intelligence based character values developed through inbound and outbound activities can positively contribute towards the improvement of character quality of junior high school students.

\section{CONCLUSIONS}

This research is a model development research on multiple-intelligence based character education management for ethos empowerment of junior high school students in the province of Gorontalo of Indonesia. This model development has become one of the alternatives to improve character education quality at secondary school level by a rounded teaching and learning management system. The implementation of the character education management can be found in teaching and learning process that is designed and implemented by developing intellectual, emotional, and spiritual intelligences of students through integrated character 
education program in classrooms as well as through inbound and outbound school activities, e.g. boy scout, red-cross/health unit, and school environment.

This research develops a book's model of character education management to empower ethos transformation based on multiple-intelligence for junior high school students, which involving: guidelines on fundamental concepts, programs, implementation, and monitoring and evaluation. The results of the first year research include: (1) developed Book I Draft on Basic Concepts in Managing MultipleIntelligence based Education Management; (2) developed Book II Draft on Multiple-Intelligence based Character Education Model; (3) developed Book III Draft on Implementation Guidelines of Multiple-Intelligence based Character Education; and (4) developed Book IV on Monitoring and Evaluation Guidelines of MultipleIntelligence based Character Education.

\section{REFERENCE}

[1] [1] Acemoglu and Robinson. (2012). Why Nation Fail; The Origin of Power, Prosperity and Poverty. Profile Books LTD. London

[2] [2] Maarif, A. Syafi'i. ( 2011). Borok Itu Kian Mengapung. Kompas (09/7/2011) Jakarta. PT. Gramedia

[3] [3] Prasodjo, Eko. (2011). Revitalisasi Negara. Kompas (4/7/ 2011). Jakarta. PT. Gramedia.

[4] [4] Robinson-Lee. (2008). A Framework for Understanding Character Education in Middle schools. ProQuest Dissertations and Theses. Retrieved from http://search.proquest.com/docview

[5] [5] Revell, L. \& Arthur, J. (2007). Character education in schools and the education of teachers. Journal of Moral Education, 36(1), 79-92. Responsibility. The New York Times Company.

[6] [5] Hudd, S. S. (2010). Middle school students' perceptions of character education: What they are doing when someone is. Sociological Studies of Children and Youth, 13, 267-293. Emerald Publishing Group, Bingley, UK. Retrieved from http://search.proquest.com/docview,

[7] [6] Wagner, B. P. (2008). The principal's perception of character education implementation in California middle schools based on the eleven principles of character education. ProQuest Dissertations and Theses. University of La Verne

[8] [7] Lickona,T. (1991). Educating For Character. How Our Schools Can Teach Respect and Responsibility. The New York Times Company

[9] [8] Suyanto. (2011). Urgensi Pendidikan Karakter. Kompas (05/7/2011). Jakarta. PT. Gramedia

[10] [9] Kashwer, J. J. (2009). Character education program: Impact and outcome on student behavior in a California middle school. Dissertation Abstracts International Section, ProQuest Information \& Learning. Retrieved from http://ezproxy.umsl.edu/login?url=http://search.ebscohost.

[11] [10] Borg \& Gall. (2003). Educational Reseach. New York. Alyen \& Bacon

[12] [12] Boyatzis, R.E., Goleman, \& Rhee, K. (1999). Clustering Competence in Emotional Intelligence:Insights from the Emotional Competence Inventory (ECI).http://www.eiconsortium.org

[13] [13] Ledford, A. T. (2011). Professional development for character education: An evaluation of teachers' sense of efficacy for character education. Scholar-Practitioner Quarterly, 5,256-273.

[14] [14] Goleman D. (1995). Emotional Intelligence, Kecerdasan Emosional, Mengapa EI Lebih Penting daripada IQ. transeleted by Hermaya. Jakarta: Gramedia Pustaka Utama

[15] [15] Masaong, A.K. (2011). Kepemimpinan Berbasis Multiple Intelligence; Memperteguh Sinergy Kecerdasan Intelektual, Emosional, dan Spiritual untuk Meraih Prestasi Gemilang. Bandung: Alfabetha.

[16] [16] Gardner, H.(2011). Frame of Mind: The Theory of MultipleIntelligence. NewYork. Basic Book

[17] [17] Caldwell. B.J \& Spink, JM. 1992. Leading The Self Managing School. London: The Falmer Press
[18] [18] Ekosusilo, M. (2003). Sistem Nilai Dalam Budaya Organisasi Sekolah Pada Unggul (Studi Kasus di SMU Negeri 1, SMU Regina Pacis, dan SMU al-Islam 01 Surakarta) (Disertasi Malang State Unuversity unpublicated ).

[19] [19]Schein,(1992). Organizatinonal Culture and Leadership. San Fracisco:Joosey-Bass Publishers. Study.http://www.toto@ cps-sss.org

[20] [20] Bulach, C. R. (2002). Implementing a character education curriculum and assessing its impact on student behavior. The Clearing House, 76(2), 79-83. Retrieved http://search.proquest.com/docview/196877115?accounti

[21] [21] Rickermann, M. T. (2011). The Impact of Character Education Curriculum on Misconduct Violations and Middle School Teachers' Perceptions of the Effectiveness of Character Education Curriculum. ProQuest Dissertations and Theses. Missouri Baptist University. Retrieved from http://search.proquest.com.ezproxylocal.library. 